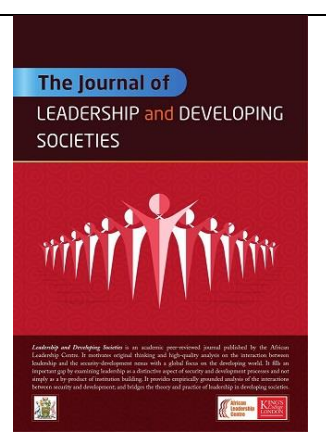

COMMENTARY

\title{
Leadership and Peacebuilding: The Role of Young People in Countering Violent Extremism in North East Nigeria
}

Ibrahim Mohammed Machina ${ }^{a}$

Available online 23 December 2020

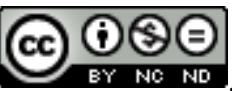

\begin{abstract}
The involvement of some young people as foot soldiers of extremist groups has led to the stereotype of youth in general as perpetrators of violence and a threat to peace and stability. That is why many commentaries and media reportage on Nigeria portray young people as perpetrators of violence or victims of conflict. However, this picture of young people is incomplete because it fails to acknowledge the role of young people as peacebuilders. This commentary examines the role of young people in countering violent extremism in North East Nigeria and focuses on the North East Intellectual Entrepreneurship Fellowship (NEIEF) Fellows as a case study. I argue that young people who actively joined extremist groups represent a small minority of the youth population. The majority of young people in North East Nigeria have been actively working to counter extremist narratives of violence.
\end{abstract}

Keywords: Boko Haram; Nigeria; countering violent extremism; youth agency, African peacebuilding; mutuality

\section{INTRODCTION}

Since 2009, violent atrocities by Boko Haram have caused devastating consequences in North East Nigeria and the Lake Chad region at large. Boko Haram has been most active in Northeastern states of Borno, Yobe and Adamawa. The group capitalized on societal factors that made young people vulnerable to persuade them to join their group to unleash terror on Nigerians. A majority of young people who joined Boko Haram are influenced by social or business peers who lured them with the promise of opportunities to prosper economically and socially. Coupled with the inability of government to respond to societal challenges such as poverty, unemployment, economic inequalities and exclusion of young people in decision-making processes, this created the space and context that drives young people to join Boko Haram. ${ }^{1}$ When Boko Haram emerged in 2002, for example, before they turned violent, many communities supported the group thinking they will provide the necessary societal changes and development.

\section{CONTEXT: YOUTH AND CONFLICT IN NORTH EAST NIGERIA}

Young people play crucial roles as change agents. They use every opportunity to prove their capacity by

\footnotetext{
a Fellow on the African Leadership Centre's 2019/20 Peace and Security Fellowship Programme for Young African Scholars Email: ibrahim.machina@kcl.ac.uk

1 Onuoha, F.C. (2014), Why Do Youth Join Boko Haram? Special Report 348, (Washington: United States Institute of Peace); Motivations and Empty Promises: Voices of Former Boko Haram Combatants and Nigerian Youth (2016), Mercy Corps
} 
creating innovative ideas and approaches to build peace. However, in North East Nigeria, the potential of young people to be change agents was undermined by societal challenges such as poverty, unemployment, economic inequalities and exclusion from decision-making process.

These challenges isolated many young people in the region and pushed some towards violent extremism and their involvement led many to paint young people in general as perpetrators and a threat to peace and stability in the region. However, recent studies show that young people who actively joined extremist groups represent a small minority of the youth population. ${ }^{2}$ The majority of young people are not violent, they have rejected violence and are working to promote peace in their communities. ${ }^{3}$ One of the mechanisms used by the extremists to recruit their followers is strategic communication where they present their messages using the internet. They believe they are waging a holy war to establish an Islamic State. ${ }^{4}$

Boko Haram manipulates religion and targets vulnerable people, more especially young people with grievances, and offers a remedy to their current predicament. The group uses selected teachings of Islam, which is the predominant religion in North East Nigeria, to justify their atrocities. ${ }^{5}$ They promote their propaganda through the internet using social media to upload their messages via videos to depict the group as promoter of social justice and good governance. They also send messages to claim attacks, provide justification for attacks and warn against future attacks. They use these messages to raise awareness about their group and recruit vulnerable individuals. ${ }^{6}$

\section{LEADERSHIP EMERGENCE OF NEIEF FELLOWS}

Most peacebuilding efforts focus on the role of positionbased leaders who occupy assigned positions in the formal decision-making process. ${ }^{7}$ However, this fails to recognize the role of individuals who play prominent

\footnotetext{
2 Youth Strategy 2014-2017: Empowered Youth, Sustainable Future (2014), UNDP

${ }^{3}$ Ekpon, T. (2017), The Role of Young People in Preventing Violent Extremism in the Lake Chad Basin, (Hague: Civil Society Platform for Peacebuilding and Statebuilding)

4 Walker, Andrew (2012), What is Boko Haram? Special Report 308 (Washington: United States Institute of Peace)

${ }^{5}$ Kerim, B. (2014), Military option alone can't win Boko Haram insurgency, (Abuja: The Nation Newspaper)
}

roles in building peace without occupying any formal position. Peter Northouse defines leadership as the process of influencing people to achieve a shared goal. ${ }^{8}$ The emergence of NEIEF fellows represents individuals without formal positions in the decision-making process working to build peace in their societies and to exercise influence. The fellows participated in the \#NotAnotherNigerian social media campaign which is as an alternate mechanism to respond to Boko Haram propaganda and recruitment drive online. Since Boko Haram uses social media to promote their extremist narratives and recruit young people online, to effectively overcome this threat, it became necessary to use the same platform to develop and amplify counternarratives that raise awareness of the manipulation of young people by Boko Haram. This also enables the development of alternate narratives that promote the culture of peace and creates a space for positive change in the North East. As a result, the \#NotAnotherNigerian social media campaign was launched in May 2017 with the support of the United States Agency for International Development (USAID).

The \#NotAnotherNigerian campaign began as part of the NEIEF Fellowship as a tool to combat violent extremism in North East Nigeria. It is active on Facebook, Twitter, Instagram, and Medium. A network of online influencers, including the NEIEF fellows, were tasked with using social media to credibly tell the story of the North East the way they believe it should be told, and to engage in important discussions with young people and other audiences online. The campaign was born, in part, out of a need for Nigerians to empathise with people from the North East who face destruction and displacement as a result of violent extremism. The hashtag advocates for an end to extremist attacks against Nigerians and in Nigeria. It aims to unite people in saying "Never Again" should we go through such pain as a people. Since its inception, the \#NotAnotherNigerian campaign has reached millions of users. ${ }^{9}$

${ }^{6}$ Preventing Violent Extremism in Nigeria: Effective narrative and Messaging, National Workshop Report, 23-24 May 2017, Club de Madrid

7 Olonisakin, Funmi (2017), 'Towards Re-conceptualising Leadership for Sustainable Peace' Leadership and Developing Societies, Vol. 2, No. 1

8 Northouse, Peter (2016), Leadership: Theory and Practice, 7th edn. (Los Angeles: Sage Publications)

${ }^{9}$ Battling Violent Extremism in Nigeria (2018), USAID 


\subsection{Mutuality}

There is mutuality between the NEIEF Fellows and the targeted audience in the communities because these are young people from the region. They represent voices from ordinary citizens who are affected one way or the other by the activities of the extremist group. ${ }^{10}$ NEIEF Fellows were able to inspire and influence young people online on how to safeguard themselves from falling into violent extremism and becoming radicalized. They worked across communities and religious groups to foster trust, dialogue, and mutual understanding, building social cohesion and decreasing marginalization and injustice. These messages are targeted at vulnerable people to reduce the propaganda of the extremist group because these messages by the fellows are based on true life stories and experiences that the communities can relate to. Fellows responded to radical messages with the true teaching of Islam. Thus, NEIEF Fellows developed and promoted positive narratives and counter narratives that challenged extremist narratives of violence to enable young people to resist extremist messages.

Another responsibility of the NEIEF Fellows was to contribute to the establishment of a network of young people and relevant stakeholders committed to countering violent extremism in North East Nigeria. This included reaching out, effectively communicating NEIEF objectives and encouraging young people to be part of the \#NotAnotherNigerian campaign. ${ }^{11}$ Using Crimson Hexagon, the Creative Associates Development Lab collected a total of 106,287 posts from May 29, 2017 to March 28, 2018 with the hashtag \#NotAnotherNigerian. This content was collected from social media channels including Twitter, Facebook and Instagram. Overall, the tone of the posts has been positive and hopeful. Some of the main topics of discussions centred on violent extremism and how to counter it. Other topics have included peace, youth, education, religion, social media and dialogue. As part of the initiative, the Fellows have driven many of those discussions through their own social media accounts. Additional special events such as "tweet chats" and Facebook discussions were also organised to help

10 Bass, Bernard M. \& Bass, Ruth (2008), The Bass Handbook of Leadership: Theory, Research, and Managerial Applications, 4th edn. (New York: The Free Press)

11 Machina, Ibrahim Mohammed, Ahmed, Amina Garuba \& Babangida, Ishaka Mohammed (2018), 'Youth Contributions to broaden the audience and engagement of the Fellows. In 2018, members of the campaign presented their work in Nigeria's Social Media Week in Lagos, an event with close to 20,000 participants. ${ }^{12}$

Notwithstanding the mutuality shared between NEIEF Fellows and young people in the local communities they are from, maintaining the activities surrounding the launch of the \#NotAnotherNigerian campaign was bound to be difficult in the absence of continuous support. Uptake on various social media platforms was varied and continuation of the campaign would later rely on the reach of individual Fellows on social media and the extent of their networks. Initiatives inspired by or supported by external actors are difficult to sustain while organic or homegrown initiatives that are backed by sustainable local resources might be longer lasting. In hindsight, the absence of local organisational or governmental support for this campaign was a gap that limited the capacity of Fellows to expand their reach. Their influence was invariably limited to their local environment and individual social networks.

\section{CONCLUSION}

The experience of the \#NotAnotherNigerian campaign and the efforts of the NEIEF Fellows shows that young people in North East Nigeria are important drivers and agents of change. Young people like NEIEF Fellows demonstrated openness to change and learning. They tend to be more future-oriented, more idealistic and innovative, and more willing to take risks by using social media to open discussions on issues ranging from countering violent extremism to gender equality and social inclusion. This is why it is vital that governments and relevant stakeholders recognize the special contributions of such groups and engage them as partners. In addition, there is need for government and relevant stakeholders to adopt a broad national response that builds mutuality between the government and citizens to provide governance that meets the people's needs such as security, economic livelihood and social justice. The involvement of local and national stakeholders might ensure that initiatives such as the one led by NEIEF Fellows with the support of USAID could be sustained over the medium to long term.

the Prevention of Violent Extremism in North East Nigeria: The Case of the NEEIF Fellows', in Celina Del Felice and Obi Peter Onyeigwe, eds., Youth in Africa, Agents of Change (Madrid: Casa Africa)

12 USAID (2018) Battling Violent Extremism in Nigeria, USAID 


\section{BIBLIOGRAPHY}

Bass, Bernard M. \& Bass, Ruth (2008), The Bass Handbook of Leadership: Theory, Research, and Managerial Applications, $4^{\text {th }}$ edn. (New York: The Free Press)

Ekpon, T. (2017), The Role of Young People in Preventing Violent Extremism in the Lake Chad Basin (Hague: Civil Society Platform for Peacebuilding and Statebuilding)

Kerim, B. (2014), Military option alone can't win Boko Haram insurgency (Abuja: The Nation Newspaper)

Machina, Ibrahim Mohammed, Ahmed, Amina Garuba \& Babangida, Ishaka Mohammed (2018), 'Youth Contributions to the Prevention of Violent Extremism in North East Nigeria: The Case of the NEEIF Fellows', in Celina Del Felice and Obi Peter Onyeigwe, eds., Youth in Africa, Agents of Change (Madrid: Casa Africa)

Northouse, Peter (2016), Leadership: Theory and Practice, $7^{\text {th }}$ edn. (Los Angeles: Sage Publications)

Olonisakin, Funmi (2017), 'Towards Re-conceptualising Leadership for Sustainable Peace' Leadership and Developing Societies, Vol. 2, No. 1

Onuoha, F.C. (2014), Why Do Youth Join Boko Haram? Special Report 348, (Washington: United States Institute of Peace)

'Preventing Violent Extremism in Nigeria: Effective Narrative and Messaging', National Workshop Report, 23-24 May, 2017, Club de Madrid

Walker, Andrew (2012), What is Boko Haram? Special Report 308 (Washington: United States Institute of Peace)

Youth Strategy 2014-2017: Empowered Youth, Sustainable Future (2014), UNDP 